\title{
Global tree-ring response and inferred climate variation following the mid-thirteenth century Samalas eruption
}

\author{
Ulf Büntgen 1,2,3,4 . Sylvie Hodgson Smith ${ }^{1}$. Sebastian Wagner ${ }^{5} \cdot$ Paul Krusic $^{1,6}$. Jan Esper ${ }^{2,7}$. Alma Piermattei ${ }^{1}$. \\ Alan Crivellaro ${ }^{1,8} \cdot$ Frederick Reinig $^{7} \cdot$ Willy Tegel $^{9} \cdot$ Alexander Kirdyanov $^{10,11} \cdot$ Mirek Trnka $^{2} \cdot$ Clive Oppenheimer $^{1}$
}

Received: 12 August 2021 / Accepted: 5 January 2022 / Published online: 16 January 2022

(c) The Author(s) 2022

\begin{abstract}
The largest explosive volcanic eruption of the Common Era in terms of estimated sulphur yield to the stratosphere was identified in glaciochemical records 40 years ago, and dates to the mid-thirteenth century. Despite eventual attribution to the Samalas (Rinjani) volcano in Indonesia, the eruption date remains uncertain, and the climate response only partially understood. Seeking a more global perspective on summer surface temperature and hydroclimate change following the eruption, we present an analysis of 249 tree-ring chronologies spanning the thirteenth century and representing all continents except Antarctica. Of the 170 predominantly temperature sensitive high-frequency chronologies, the earliest hints of boreal summer cooling are the growth depressions found at sites in the western US and Canada in $1257 \mathrm{CE}$. If this response is a result of Samalas, it would be consistent with an eruption window of circa May-July 1257 CE. More widespread summer cooling across the mid-latitudes of North America and Eurasia is pronounced in 1258, while records from Scandinavia and Siberia reveal peak cooling in 1259. In contrast to the marked post-Samalas temperature response at high-elevation sites in the Northern Hemisphere, no strong hydroclimatic anomalies emerge from the 79 precipitation-sensitive chronologies. Although our findings remain spatially biased towards the western US and central Europe, and growth-climate response patterns are not always dominated by a single meteorological factor, this study offers a global proxy framework for the evaluation of paleoclimate model simulations.
\end{abstract}

Keywords Climate models · Climate reconstructions · Dendrochronology · Growth response · Hydroclimate · Paleoclimate $\cdot$ Temperature change $\cdot$ Tree rings $\cdot$ Volcanic eruptions

Ulf Büntgen

ulf.buentgen@geog.cam.ac.uk

1 Department of Geography, University of Cambridge, Cambridge CB2 3EN, UK

2 Global Change Research Institute (CzechGlobe), Czech Academy of Sciences, 60300 Brno, Czech Republic

3 Department of Geography, Faculty of Science, Masaryk University, 61137 Brno, Czech Republic

4 Swiss Federal Research Institute (WSL), 8903 Birmensdorf, Switzerland

5 Institute of Coastal Systems, Analysis and Modeling, Helmholtz-Zentrum Hereon, 21502 Geesthacht, Germany

6 Department of Physical Geography, Stockholm University, 10691 Stockholm, Sweden
7 Department of Geography, Johannes Gutenberg University, 55099 Mainz, Germany

8 Forest Biometrics Laboratory, Faculty of Forestry, "Stefan Cel Mare" University of Suceava, 720229 Suceava, Romania

9 Chair of Forest Growth and Dendroecology, Institute of Forest Sciences, Albert Ludwig University of Freiburg, Tennenbacherstr. 4, 79106 Freiburg, Germany

10 Institute of Ecology and Geography, Siberian Federal University, Krasnoyarsk 660041, Russia

11 V.N. Sukachev Institute of Forest SB RAS, Federal Research Centre, Krasnoyarsk 660036, Russia 


\section{Introduction}

As recorded in polar ice cores, the largest volcanic sulphur release to the atmosphere in at least the past 2500 years occurred between 1257 and 1259 CE (hereinafter all calendar dates refer to the Common Era; CE) (Palais et al. 1992; Oppenheimer 2003a; Sigl et al. 2015). The source of this eruption was eventually identified as Samalas volcano, part of the Rinjani complex on Lombok Island, Indonesia (Lavigne et al. 2013). Though the eruption's great magnitude and intensity (Lavigne et al. 2013; Vidal et al. 2015) and glaciochemical and petrological evidence (Sigl et al. 2015; Vidal et al. 2016, respectively) for a sulphur yield exceeding that of the Tambora eruption in 1815 (Oppenheimer 2003b) are undisputed, Samalas' atmospheric and climatic responses have been subject to enduring debated (Stothers 2000; D'Arrigo et al. 2005; Timmreck et al. 2009; Timmreck 2012; Schmidt and Robock 2015; Guillet et al. 2017; Wade et al. 2020). Moreover, climate models, which are sensitive to parametrisation of the amplitude and timing of radiative forcing (Jungclaus et al. 2017), suggest a stronger and more prolonged Northern Hemisphere (NH) summer cooling than that found in tree ring-based temperature reconstructions (Anchukaitis et al. 2012; Mann et al. 2012).

In the absence of a firm historical date or cosmogenic tie-point for radiocarbon dating of relict wood samples (Büntgen et al. 2018; Reinig et al. 2021), fixing the year of an eruption typically combines evidence from ice cores (e.g., sulphur and/or ash), historical sources (e.g., records attesting to stratospheric aerosol veils), proxy-based climate reconstructions, and model-based climate simulations. Yet in the case of Samalas, there is no robust combination of evidence that can discriminate between 1257 or 1258 as the year of eruption. Stothers (2000) argued for early 1258, while Oppenheimer (2003a) and Lavigne et al. (2013) have suggested 1257. Although the earlier date is the more widely quoted, the arguments in favour are not watertight. For instance, they include documentary evidence for mild January conditions in 1258 over France (Lavigne et al. 2013) without mentioning that the association of large volcanic eruptions and $\mathrm{NH}$ winter warming (Zambri et al. 2017) is still disputed (Polvani and Camargo 2020).

Even less coherent is the available climate proxy and model evidence of the regional and global hydroclimatic response to sulphur-rich eruptions (Rao et al. 2017; Liu et al. 2020). While models simulate regional-scale precipitation deficits in South, East and Southeast Asia (Schneider et al. 2009; Iles et al. 2013), the sparse annually-resolved reconstructions in those regions show generally weak signals (Anchukaitis et al. 2010). Further complications in untangling the post-volcanic response patterns arise from the dynamical interactions amongst other modes of climate variability on radiative forcing, including the position of the Intertropical Convergence Zone (ITCZ) (Tejedor et al. 2021a), and both the phasing and intensity of the El-Niño Southern Oscillation (ENSO) (Dee et al. 2020; Predybaylo et al. 2020) and Atlantic Multidecadal Oscillation (AMO) (Mann et al. 2021).

The latest generation of annually-resolved and absolutelydated summer temperature reconstructions for different parts of the $\mathrm{NH}$, either using tree-ring width (TRW) (Büntgen et al. 2020, 2021), maximum latewood density (MXD) (Schneider et al. 2015), or a combination thereof (Stoffel et al. 2015; Wilson et al. 2016), all register distinct cold spells in 1258 and 1259 (Fig. 1a, b). The MXD-based cooling signal recovers rapidly after 1258 (Esper et al. 2015), the TRW-MXD hybrids reveal a 2-year post-eruption cold period, and the TRW-only reconstruction exhibits lowest temperatures in 1259. These differences arguably reflect the slightly 'redder' power spectrum in TRW than MXD chronologies (Franke et al. 2013; Büntgen et al. 2020), since the latter are generally less affected by biological memory (Büntgen et al. 2006; Esper et al. 2013). While too much persistence in specific TRW chronologies can be a possible disadvantage for reconstructing the amplitude and duration of climatic extremes (Ljungqvist et al. 2020), there are still too few MXD chronologies spanning the past millennium (Schneider et al. 2015; Esper et al. 2016).

The estimated annual, NH extra-tropical, Stratospheric Sulphate Aerosol Optical Depth (SAOD) signature from Samalas occurs in 1258 (Toohey and Sigl 2017). This is consistent with the strongest cooling seen in the tree ringbased reconstructions (Fig. 1c, d). The temperature-SAOD link has been corroborated by independent wood anatomical evidence from the Spanish Pyrenees (Fig. 1e), matching the occurrence of distinct Blue Rings to severe ephemeral cooling during summer 1258 (Büntgen et al. 2017; Piermattei et al. 2020). Considering all the available climate proxies for the NH extra-tropics (Fig. 1), and our general understanding of volcanic forcing of the Earth's climate system (Gao et al. 2008; Timmreck 2012; Stenchikov 2021), global patterns in the temperature and hydroclimate response to the $\sim 1257$ Samalas eruption remain unclear. This adds to the challenge of unravelling the direct and indirect interrelationships between climate variability and human history in the aftermath of the event (Guillet et al. 2017; Di Cosmo et al. 2021).

Here, we present a near-global network of 249 TRW chronologies from six continents to reconstruct the temperature and precipitation fingerprints of the Samalas eruption. More specifically, we aim to (1) narrow the time window of the eruption, (2) detect hydroclimatic responses, (3) identify and quantify any response in the Southern Hemisphere (SH), and 


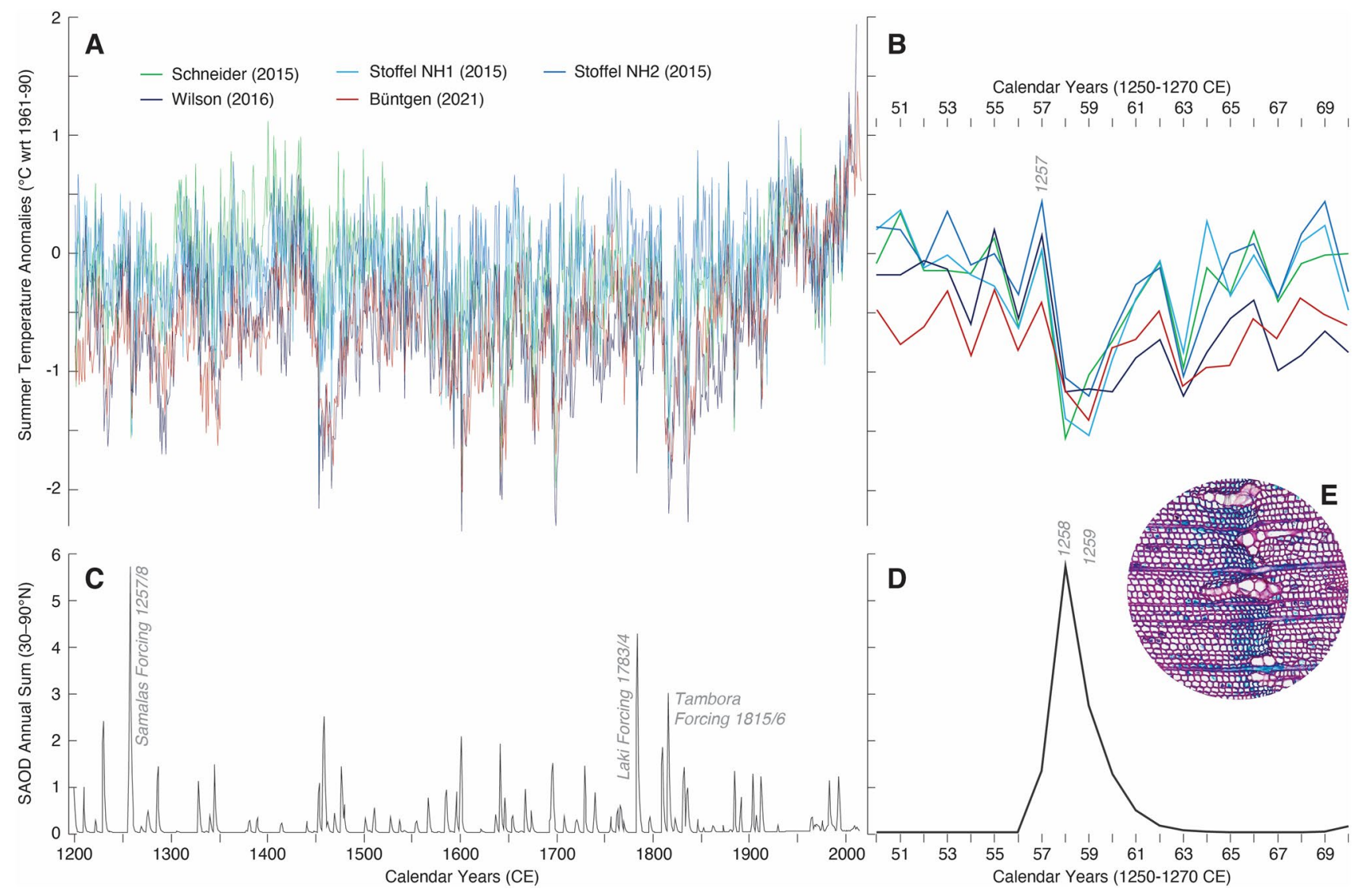

Fig. 1 a Five tree ring-based summer temperatures reconstructions that either use ring widths (Büntgen et al. 2021), maximum latewood densities (Schneider et al. 2015), or different combinations thereof (Stoffel et al. 2015; Wilson et al. 2016). Each timeseries has been scaled against the 1961-90 June-August (JJA) average instrumental temperature anomalies over the $30^{\circ}-70^{\circ} \mathrm{N}$ extra-tropical landmass. b The five reconstructions exhibit a sharp depression in 1258 followed

(4) describe the overall spatiotemporal pattern of climate variability following the eruption. Furthermore, we compare our high-resolution proxy evidence from the thirteenth century against output from state-of-the-art paleoclimate model simulations, discuss agreement and disagreement in the context of natural climate dynamics, and make recommendations for research priorities concerning the volcanoclimate interface.

\section{Materials and methods}

\subsection{Tree-ring width chronologies}

We compiled raw TRW measurements between 1200 and 1300 from 249 sites on all continents except Antarctica (Fig. 2). Most of the data come from the ITRDB and represent North America (122 sites) and Europe (78 sites). Six sites are in the northern boreal forest of Siberia, and another by parameter-specific recovering rates of up to one decade. $\mathbf{c}, \mathbf{d}$ Ice core-based estimates of the total annual Stratospheric Aerosol Optical Depth (SAOD) averaged over $30^{\circ}-90^{\circ} \mathrm{N}$ (Toohey and Sigl 2017). e A double-stained, wood anatomical thin section of a Mountain pine (Pinus uncinata) from the upper treeline $\sim 2200 \mathrm{~m}$ asl in the central Spanish Pyrenees (Piermattei et al. 2020), showing a lack of cell wall lignification and frost damage in 1258

18 represent high-elevation treeline ecotones in central Asia. Only one site in Vietnam is in the tropics, $2000 \mathrm{~km}$ north of Lombok (Fig. 2 insert photograph). Compared to the 232 sites in the $\mathrm{NH}$, there are just 17 sites in the SH covering the entire thirteenth century, two in New Zealand and Chile, three in Tasmania, and ten in Argentina. With only four sites in Morocco and one in Algeria, Africa is considerably underrepresented. The average site elevation is $1550 \mathrm{~m}$ asl, with a maximum range from 0 to $4350 \mathrm{~m}$ asl. The lowest elevation trees are oaks in the Netherlands, and highest are junipers on the Tibetan Plateau. Most of the sites are located either below $500 \mathrm{~m}$ asl (93 sites) or between 2000 and $4000 \mathrm{~m}$ asl (102 sites). The network is composed of 205 conifer and 44 broadleaf species (see Fig. 2 for further details on site and species distribution).

After considering each species' physiological requirements and biogeographic setting at each site, we divided the TRW chronology network into two climate response archetypes, one containing 170 sites where tree growth is 


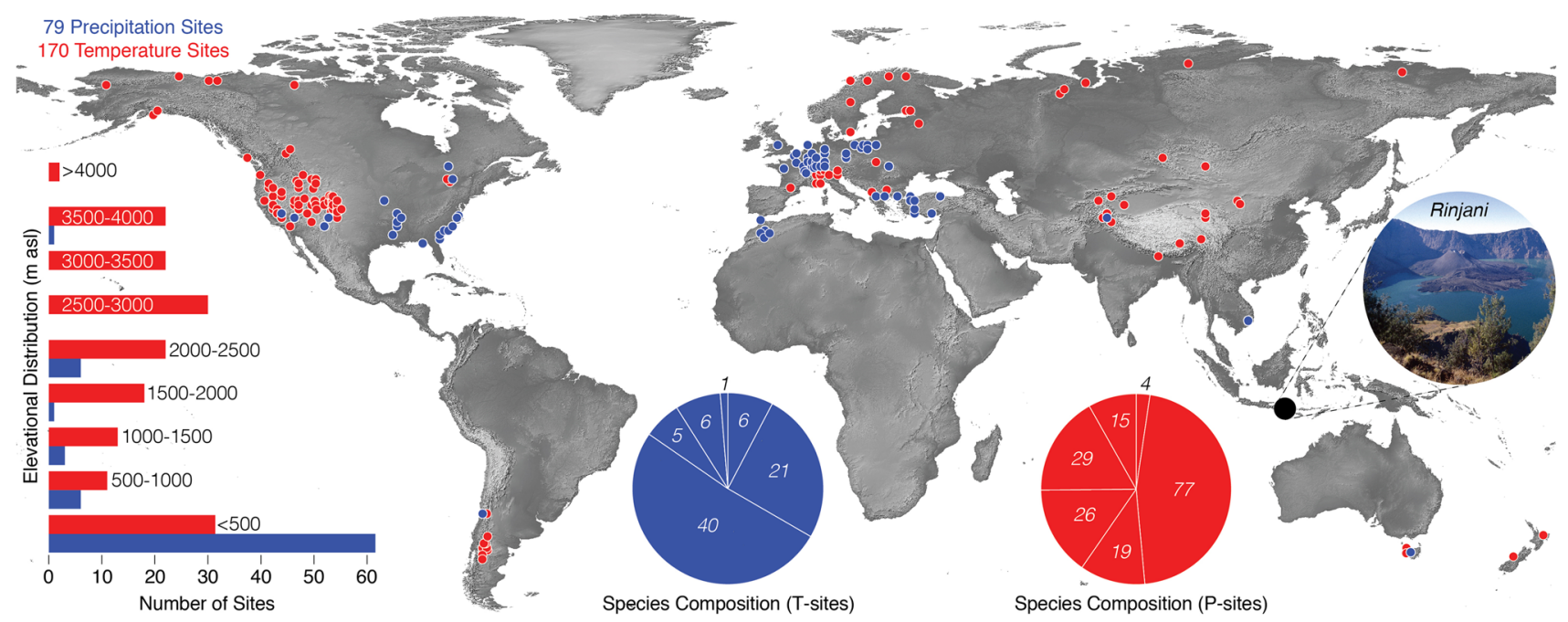

Fig. 2 Global distribution of 249 regional tree-ring width (TRW) chronologies (dots), classified into 79 and 170 sites where either precipitation (blue) or temperature (red) is considered the predominant growth control (some dots overlap). The elevational range of the 79 precipitation-sensitive sites is $0-3500 \mathrm{~m}$ asl, with a mean of 435 and a median of $180 \mathrm{~m}$ asl. The elevational range of the 170 temperature-

predominantly controlled by changes in warm-season temperature and another containing 79 mainly precipitation-limited sites (Fritts 1976), respectively. Though one may argue the growth-climate association of some TRW datasets in this collection would have been better described as a mixed signal (see "Discussion" for details), our binary classification was necessary for comparison with independent model simulations. We therefore followed the general assumption that conifer growth at the upper elevational and latitudinal, species-specific distribution limit is mainly temperature dependent, whereas tree growth at lower elevations under temperate and arid conditions typically depends on precipitation-driven soil moisture availability (see St. George 2014 for a $\mathrm{NH}$ perspective).

During the thirteenth century (1200-1300), the average number of raw TRW measurement series in the individual datasets is 15 series, with an average minimum and maximum replication of 11 and 18 series, respectively. To remove effects of the biological age-trend, non-stationary noise and heteroscedasticity from the raw TRW measurements (Cook and Peters 1981), we used individual cubic smoothing spline functions with $50 \%$ frequency cut-off at 20 years. This rather conservative standardisation technique emphasizes interannual to decadal growth variability but suppresses any lower frequency information (Cook et al. 1995; Helama et al. 2004; Battipaglia et al. 2010). The high-frequency TRW site chronologies were derived from bi-weight robust means, and their temporal variance was stabilized (Osborn et al. 1997). All detrending and chronology development steps were performed by the latest version of the ARSTAN software sensitive sites is $50-4350 \mathrm{~m}$ asl, with a mean of 2069 and a median of $2205 \mathrm{~m}$ asl. The composition of the 79 precipitation-sensitive sites includes Quercus sp. (40), Cupressaceae (21), Pinus sp. (6), Pinaceae (6), Juniperus sp. (5), and Larix sp. (1). The composition of the 170 temperature-sensitive sites is Pinus sp. (77), Pinaceae (29), Juniperus sp. (26), Cupressaceae (19), Larix sp. (15), and others (4)

(Cook et al. 2017). To further explore chronology robustness, we applied 40-year spline functions and tested for the effects of power-transformation before detrending (Cook and Peters 1997). Since neither the different spline functions nor the power-transformation had significant effects on the resulting TRW chronologies. We decided to proceed with the 20-year spline versions. The resulting chronologies were then normalized over their common period 1200-1300 (i.e., transformed to have a mean of zero and a standard deviation of one). The normalized TRW indices were plotted and mapped in QGIS 3.10.13 (QGIS Development Team 2020). To account for the different phasing of extra-tropical growing seasons between hemispheres (Schulman 1956), all TRW chronologies from the SH were lagged by approximately 6 months (Büntgen and Oppenheimer 2020).

\subsection{Climate model simulations}

For proxy-model comparison (Braconnot et al. 2012; Phipps et al. 2013; PAGES2K-PMIP3 Group 2015; PAGES Hydro2k Consortium 2017; Zhu et al. 2020; Tejedor et al. 2021b), we used the average simulated June-August (JJA) temperature and precipitation output between 1200 and 1300, from a suite of 12 externally forced Earth System Model simulations of the last millennium (Table 1), generated by the Paleoclimate Modelling Inter-Comparison Project 3 (PMIP3http://www.pmip3.lsce.ipsl.fr; Braconnot et al. 2011; Lohmann et al. 2013). Varying in spatial resolution (Table 1), the individual models used one of three volcanic forcing datasets based on ice core evidence from Greenland 
Table 1 Overview of the 12 externally forced climate model simulations of the last millennium, generated by the Paleoclimate Modelling InterComparison Project 3 (PMIP3; Braconnot et al. 2011) and used in this study for comparison against the dendrochronological evidence

\begin{tabular}{|c|c|c|c|c|c|}
\hline \multirow[t]{2}{*}{ Model } & \multicolumn{2}{|l|}{ Grid } & \multirow[t]{2}{*}{ Volcanic Forcing } & \multirow[t]{2}{*}{ Modelling centre/group } & \multirow[t]{2}{*}{ References } \\
\hline & Atmosphere & Ocean & & & \\
\hline BCC-CSM1.1 & $128 \times 64 \times \mathrm{L} 26$ & $360 \times 232 \times L 40$ & GA08 & $\begin{array}{l}\text { Beijing Climate Centre, } \\
\text { China Meteorological } \\
\text { Administration }\end{array}$ & Wu et al. (2013) \\
\hline CSIRO Mk3L 1-2 & $64 \times 56 \times$ L18 & $128 \times 386 \times \mathrm{L} 40$ & CU13 & $\begin{array}{l}\text { Commonwealth Scientific } \\
\text { and Industrial Research } \\
\text { Organization in collabo- } \\
\text { ration with Queensland } \\
\text { Climate Change Centre of } \\
\text { Excellence }\end{array}$ & Collier et al. (2011) \\
\hline FGOALS0-gl & $72 \times 45 \times \mathrm{L} 26$ & $360 \times 180 \times \mathrm{L} 30$ & CU13 & $\begin{array}{l}\text { Laboratory of Numerical } \\
\text { Modelling for Atmos- } \\
\text { pheric Sciences and Geo- } \\
\text { physical Fluid Dynamics. } \\
\text { Institute of Atmospheric } \\
\text { Physics, Chinese Acad- } \\
\text { emy of Sciences }\end{array}$ & $\begin{array}{l}\text { Institute of Atmospheric } \\
\text { Physics (2017) }\end{array}$ \\
\hline $\begin{array}{l}\text { *GISS-E2-R (p121, p122, } \\
\text { p124) }\end{array}$ & $144 \times 90 \times L 40$ & $288 \times 180 \times \mathrm{L} 32$ & $\begin{array}{l}\text { p121: CU13 p122: } \\
\text { GA08 p124: } \\
\text { CU13 }\end{array}$ & $\begin{array}{l}\text { NASA Goddard Institute for } \\
\text { Space Studies }\end{array}$ & $\begin{array}{l}\text { Russell et al. (1995), } \\
\text { Schmidt et al. (2006) }\end{array}$ \\
\hline CCSM4 & $288 \times 192 \times \mathrm{L} 26$ & $360 \times 384 \times \mathrm{L} 60$ & GA08 & $\begin{array}{l}\text { National Centre for Atmos- } \\
\text { pheric Research, USA }\end{array}$ & Gent et al. (2011) \\
\hline HadCM3 & $96 \times 73 \times$ L19 & $288 \times 144 \times \mathrm{L} 20$ & CR08 & Met Office Hadley Centre & Gordon et al. (2000) \\
\hline IPSL-CM5A-LR & $96 \times 95 \times$ L39 & $182 \times 149 \times \mathrm{L} 31$ & GA08 & $\begin{array}{l}\text { Institute Pierre-Simon } \\
\text { Laplace }\end{array}$ & Dufresne et al. (2013) \\
\hline *MPI-ESM-P (r1, r2, r3) & $196 \times 98 \times \mathrm{L} 47$ & $256 \times 220 \times \mathrm{L} 40$ & CR08 & $\begin{array}{l}\text { Max Planck Institute for } \\
\text { Meteorology }\end{array}$ & Giorgetta et al. (2012) \\
\hline
\end{tabular}

$\mathrm{L}=$ number of vertical layers. CR08 $=$ Crowley et al. (2008) with eruption start in September 1257. GA08=Gao et al. (2008) with the eruption start in April 1258. CU13= Crowley and Unterman (2013) with the eruption start in September 1257

and Antarctica (Crowley et al. 2008; Gao et al. 2008; Crowley and Unterman 2013).

For comparison with the individual TRW chronologies, spatial overrepresentation of the coarse output of the individual Earth System models was avoided by cluster analyses. We applied K-means cluster analysis on the latitude, longitude and growth response of all TRW chronologies in the three consecutive years of 1257,1258 and 1259 to calculate independent spatial clusters for both, temperature and precipitation sensitive TRW sites. We therefore used a pre-defined number of ten clusters to avoid too much spatial heterogeneity, which would be inappropriate to compare with the generally coarse resolution of the climate model simulations that is in the order of hundreds of kilometres. The determination of the lower limit of clusters comes from the analysis of the spatial de-correlation distance of similar climatic characteristics reflected by the TRW sites (Jones et al. 1997). The selection of ten clusters also guaranteed a minimum of three model grid points as a robust basis for the proxy-model comparison. Using K-means cluster analysis of temperature- and precipitation-sensitive TRW chronologies, we calculated for each reginal TRW cluster and each summer between 1257 and 1259 the percentage of models showing the same direction of climate response that was either positive or negative. Although comparing the direction of climate response in both the model and TRW clusters facilitates model assessment at regional scales, this technique ignores differences in the magnitude of physical climate variables (Phipps et al. 2013).

In addition, Spearman's Rank correlation coefficients were used to assess the strength of the relationship between the reconstructed and simulated summer temperature and precipitation changes for the years 1257, 1258 and 1259 at each individual TRW site (e.g., 170 TRW chronologies for temperature and 79 TRW chronologies for precipitation). All data were normalized over the common period 1200-1300 (mean of zero and standard deviation of one). Due to the spatial resolution of climate model data, different TRW sites fall within the same model grid square and may therefore introduce a reduced degree of freedom owing to spatial autocorrelation (Mets et al. 2017). This has been considered by using the effective degrees of freedom for the proxy and model data when estimating $t$ statistics and significance levels of the Spearman's Rank correlation coefficients 
(Table 2). To mitigate methodological constraints, the proxy and model data were also compared at the grid level.

\section{Results}

\subsection{Tree-ring width responses}

Growth response patterns of the 170 predominantly temperature-sensitive TRW chronologies in 1257 indicate generally positive anomalies across Eurasia, mixed responses in central Asia, and overall neutral to positive anomalies in the SH (Fig. 3). The first indication of a distinct cold spell is expressed by 24 high-elevation sites in the Sierra Nevada and Rocky Mountains of the western US and two sites in western Canada (Fig. 4). A total of 133 temperaturesensitive sites exhibits a growth decrease in 1258 . The evidence for summer cooling in 1258 is most distinct in the mid-latitudes of North America and Eurasia. By contrast, southern sites in central Asia and at high-latitudes in both hemispheres express somewhat warmer than average conditions. In 1259 a total of 117 temperature-sensitive sites exhibits a growth increase from the previous year, and the between-site variation is much reduced. While many of the high-elevation and high-latitude TRW chronologies in North America reveal positive indices, growth depressions persist or become evident in most European, Scandinavian and Siberian chronologies. Sites in central Asia, as well as South America and Australasia show mostly enhanced growth. Comparing histograms of the climate response of all 170 temperature-sensitive TRW chronologies in 1257, 1258 and 1259 highlights 1258 as the most distinctly cold summer (Fig. 3).

Growth response patterns in 1257 of the 79 predominantly precipitation-sensitive TRW chronologies indicate generally positive anomalies across the network, with a few exceptions found in the eastern US and Chile (Fig. 5), for example. The most heterogeneous behaviour is found across Europe and the Mediterranean region. In 1258, 37 precipitation-sensitive sites display a growth decrease while 42 sites show a growth increase from the previous year. The strongest growth depressions are found in the western US, whereas the strongest growth increase is found in Vietnam. Sites in the eastern Mediterranean region, central Asia and the SH all exhibit positive anomalies. Heterogeneous patterns prevail across Europe. In 1259, most of the mid-latitude sites in North America and Eurasia show the opposite response to the previous year: positive anomalies in the western US, but negative values along the east coast of the US and in Pakistan. Again, TRW patterns in the European chronologies remain ambiguous, whereas sites in the eastern Mediterranean continue to show above average growth. Reviewing the spatial response distribution of all 79 precipitation-sensitive
TRW chronologies between 1257 and 1259 reveals a similar picture for each year.

In summary, of the 170 chronologies that contain a predominant temperature signal, the first indication of a cold spell in 1257 originates from distinct growth depressions at 26 high-elevation sites in the western US and Canada (Figs. 3, 4). Widespread summer cooling across the midlatitudes in North America and Eurasia is, however, most pronounced in 1258, and many boreal records in Scandinavia and Siberia show negative growth anomalies in 1259. In contrast to the marked post-Samalas temperature response in the $\mathrm{NH}$, there is no dramatic hydroclimatic fingerprint exhibited by the 79 precipitation-sensitive chronologies.

A more detailed assessment reveals a negative relationship between the growth response of the 170 temperature-sensitive TRW chronologies and their site elevation (Fig. 6a). The correlation between lower growth rates at higher elevations is most significant in 1258 compared to the preceding and following years. An inverse, though less distinct, association is exhibited by the 79 precipitation-sensitive TRW chronologies (Fig. 6b), which indicate overall positive trends between increasing growth rates with increasing site elevation. The distribution of the growth response of the 170 temperature-sensitive TRW chronologies in 1257 and 1259 resembles the overall pattern of the thirteenth century (Fig. 7a), whereas the distribution in 1258 is skewed towards negative anomalies. The two strongest growth decreases in 1258 are associated with two high-elevation pine sites in the western US $\left(\sim 3535 \mathrm{~m}\right.$ asl, $\sim 39^{\circ} \mathrm{N}$ and $\left.\sim 104^{\circ} \mathrm{W}\right)$. The strongest growth increase in 1259 is exhibited by a pine site at slightly lower elevation in the western US (Mount Goliath; $1900 \mathrm{~m}$ asl, $\sim 40^{\circ} \mathrm{N}$ and $\sim 108^{\circ} \mathrm{W}$ ). The distribution of the growth response of the 79 precipitation-sensitive TRW chronologies in 1257, 1258 and 1259 resembles the overall pattern of the thirteenth century (Fig. 7b). The only outstanding value is the anomalous growth increase in 1258 found in a cypress chronology from Vietnam (Bidoup Nui Ba National Park; $1700 \mathrm{~m}$ asl, $\sim 12^{\circ} \mathrm{N}$ and $\sim 108^{\circ} \mathrm{E}$ ).

\subsection{Proxy-model comparisons}

Relative to the thirteenth century mean, eight models produce their lowest JJA temperature anomalies in 1258, and three models in 1259 . The lowest JJA temperature anomaly in the FGOALS-gl simulation is in 1276. Spearman's Rank correlation coefficients between the temperature-sensitive TRW chronologies and the spatially corresponding output from 12 climate model simulations of regional summer temperature anomalies in 1257, 1258 and 1259 reveal four significantly $(p<0.05)$ positive values in 1258 (Table 2$)$. This finding suggests a high degree of proxy-model coherency on regional-to continental scales due to large volcanic forcing. In 1257, the overall positive TRW temperature response in 


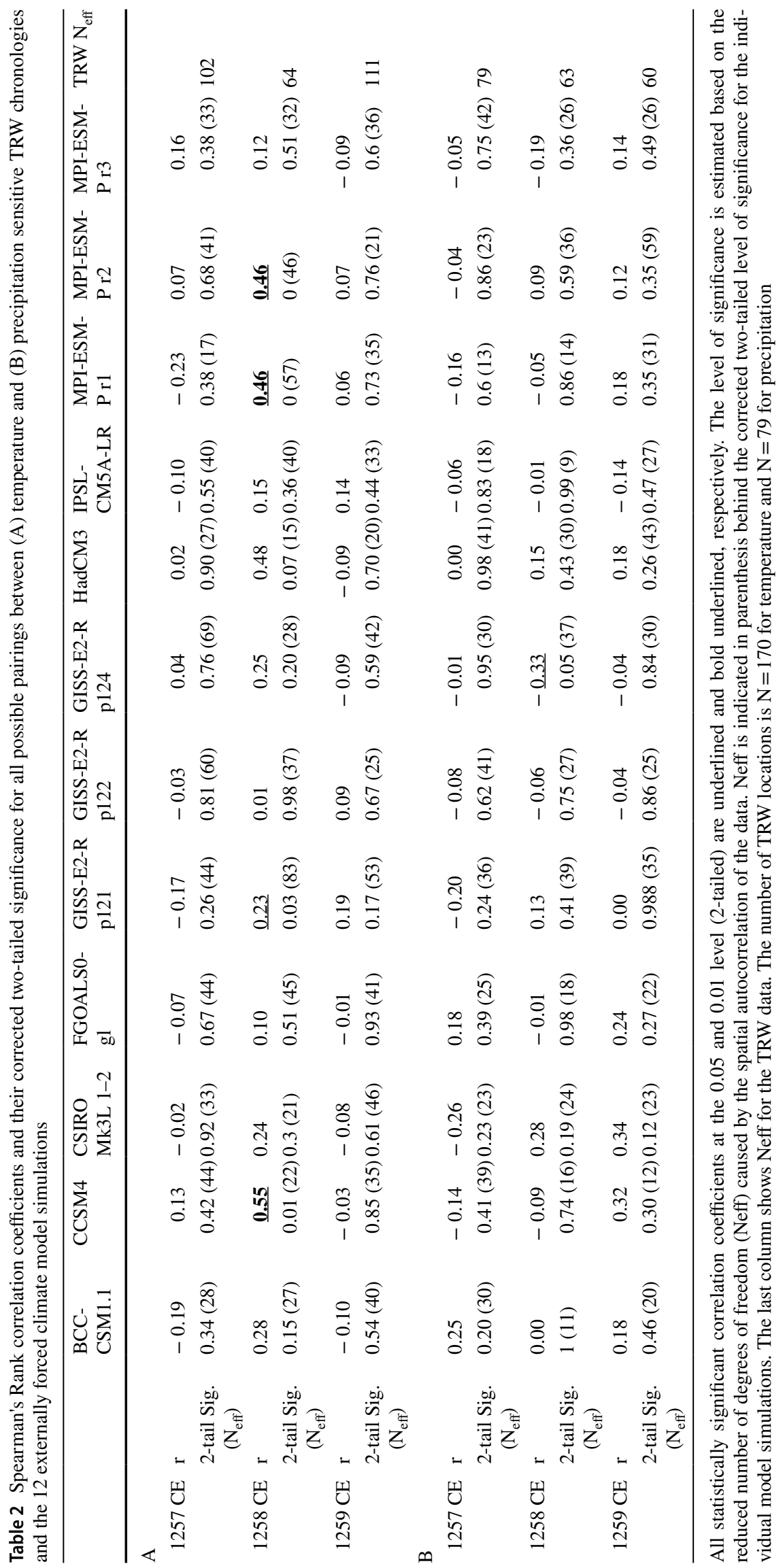



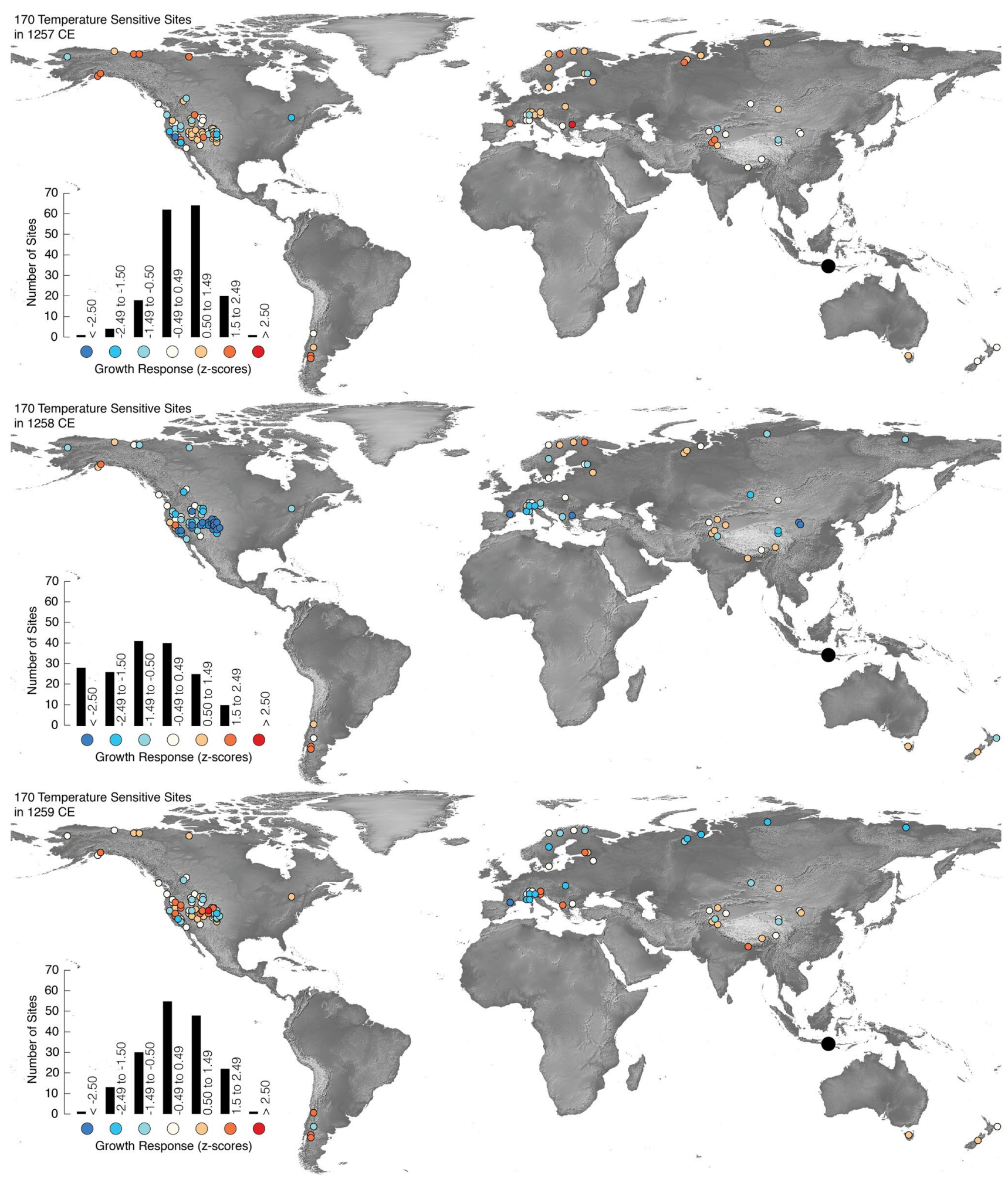

Fig. 3 Growth response of 170 temperature-sensitive tree-ring width (TRW) chronologies in 1257, 1258 and 1259 (top to bottom). Positive anomalies of the normalized proxy timeseries (with a mean of zero and a standard deviation of one for the period 1200-1300), indicative of warmer summer conditions, are shown in light orange, orange and red; negative anomalies refer to colder summer conditions and range from light to dark blue 


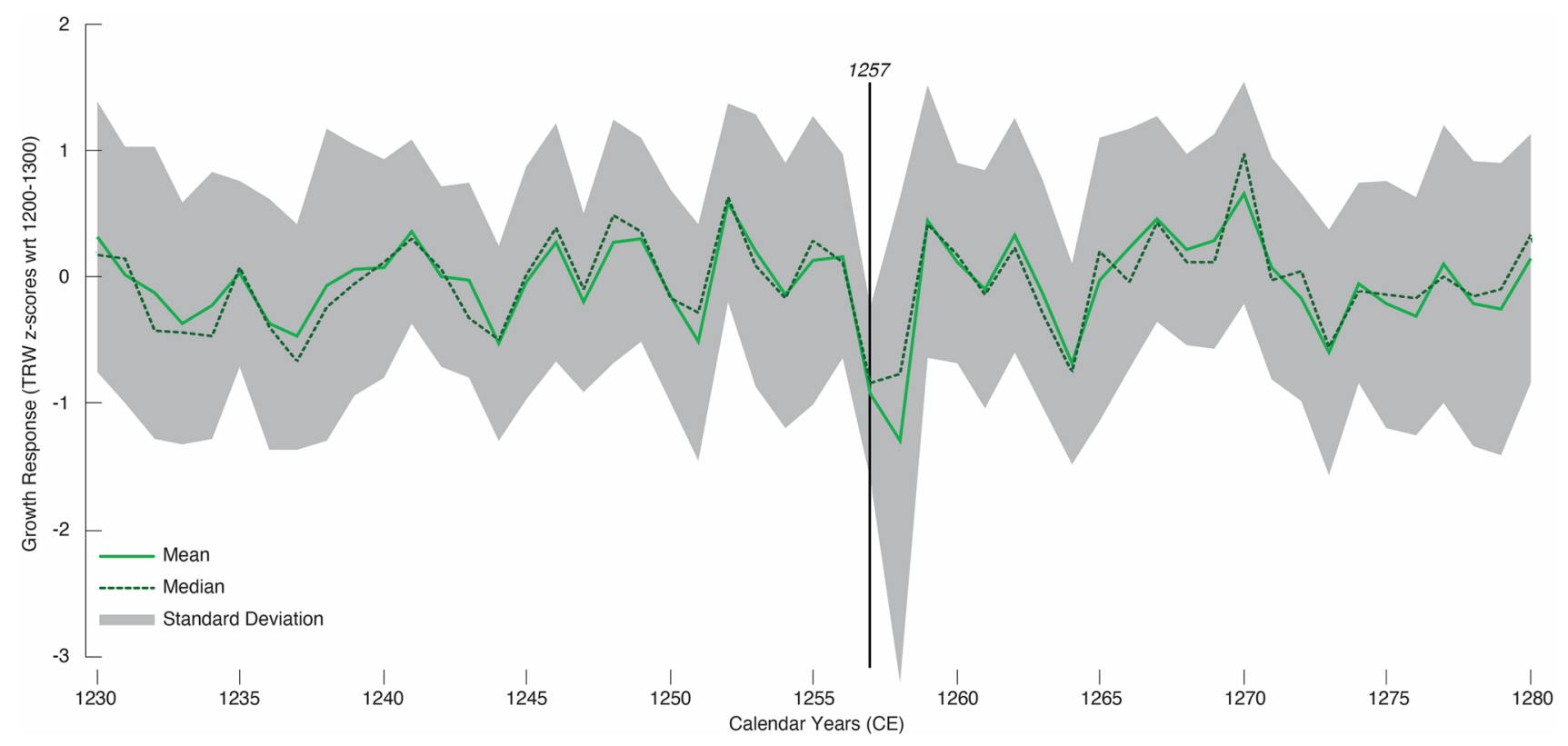

Fig. 4 Growth response of 26 temperature-sensitive tree-ring width (TRW) chronologies in the western US (\#24) and Canada (\#2) that reveal negative anomalies already in 1257. All 26 sites are located

eight spatial clusters resembles most of the model output (Fig. 8a). Similar response agreements are found in $83 \%$ of the comparisons in central Europe and central Asia, in $67 \%$ of the comparisons in Alaska and North America, in $58 \%$ of the comparisons in north-central Siberia, Australasia and South America, and in $8 \%$ of the comparisons in northern Scandinavia. In 1258, the strongest proxy-model agreement is found in North America and central Asia (both $92 \%$ ), as well as in central Europe (83\%). However, poor model agreement with positive TRW anomalies is characteristic for the high-northern latitudes and the SH. In 1259, only the TRW chronologies from central Europe and northcentral Siberia exhibit marked growth depressions, which are in line with $100 \%$ and $92 \%$ of the corresponding model data, respectively. Where TRW is positive, $25 \%$ or less of the clustered model output agrees with the reconstructed direction of response.

In contrast to the proxy-model associations of the eight temperature-sensitive TRW clusters, there are only five precipitation-sensitive TRW clusters for which sample size is sufficient to compare the directions of response (Fig. 8b). In 1257 , positive anomalies in the precipitation-sensitive TRW chronologies from the western US, western Europe and the eastern Mediterranean are reflected in 50, 42 and $50 \%$ of the models, respectively. Model agreement with negative growth responses in the eastern US and eastern Europe are 25 and $17 \%$, respectively. In 1258, positive anomalies in the precipitation-sensitive TRW chronologies in the eastern US, western Europe and the eastern Mediterranean are seen between 50 and $3660 \mathrm{~m}$ asl (with a mean and median of 2247 and $2364 \mathrm{~m}$ asl, respectively), and within $34^{\circ}-52^{\circ} \mathrm{N}$ and $104^{\circ}-126^{\circ} \mathrm{E}$

in 8, 42 and $67 \%$ of the models, respectively. Model agreement with marked negative growth responses in the western US and eastern Europe is 75\%. In 1259, positive anomalies in the precipitation-sensitive TRW chronologies from the western US, western Europe and the eastern Mediterranean are found in 58, 58 and $75 \%$ of the models, respectively. Model agreement with distinct negative growth responses in the western US and eastern Europe is $67 \%$. In summary, the spatially explicit TRW response in the $\mathrm{NH}$ provides a reasonable benchmark for model evaluation after volcanic forcing.

\section{Discussion}

Though our network contains 249 TRW chronologies from six continents, it remains spatially biased towards the western US and central Europe. Except for Algeria and Morocco, no data come from Africa, and there are only 17 sites from South America and Australasia that represent the SH (Neukom and Gergis 2011). In addition to the spatial limitations, only 79 TRW chronologies are considered precipitation sensitive, and many of the lower-elevation, mid-latitude sites in North America and Eurasia likely reflect mixed climatic signals (Galván et al. 2014; Hellmann et al. 2016). Chronologies from such sites are particularly prone to nonlinear growth responses under climatic extremes (Vitali et al. 2017; Camarero et al. 2021). 

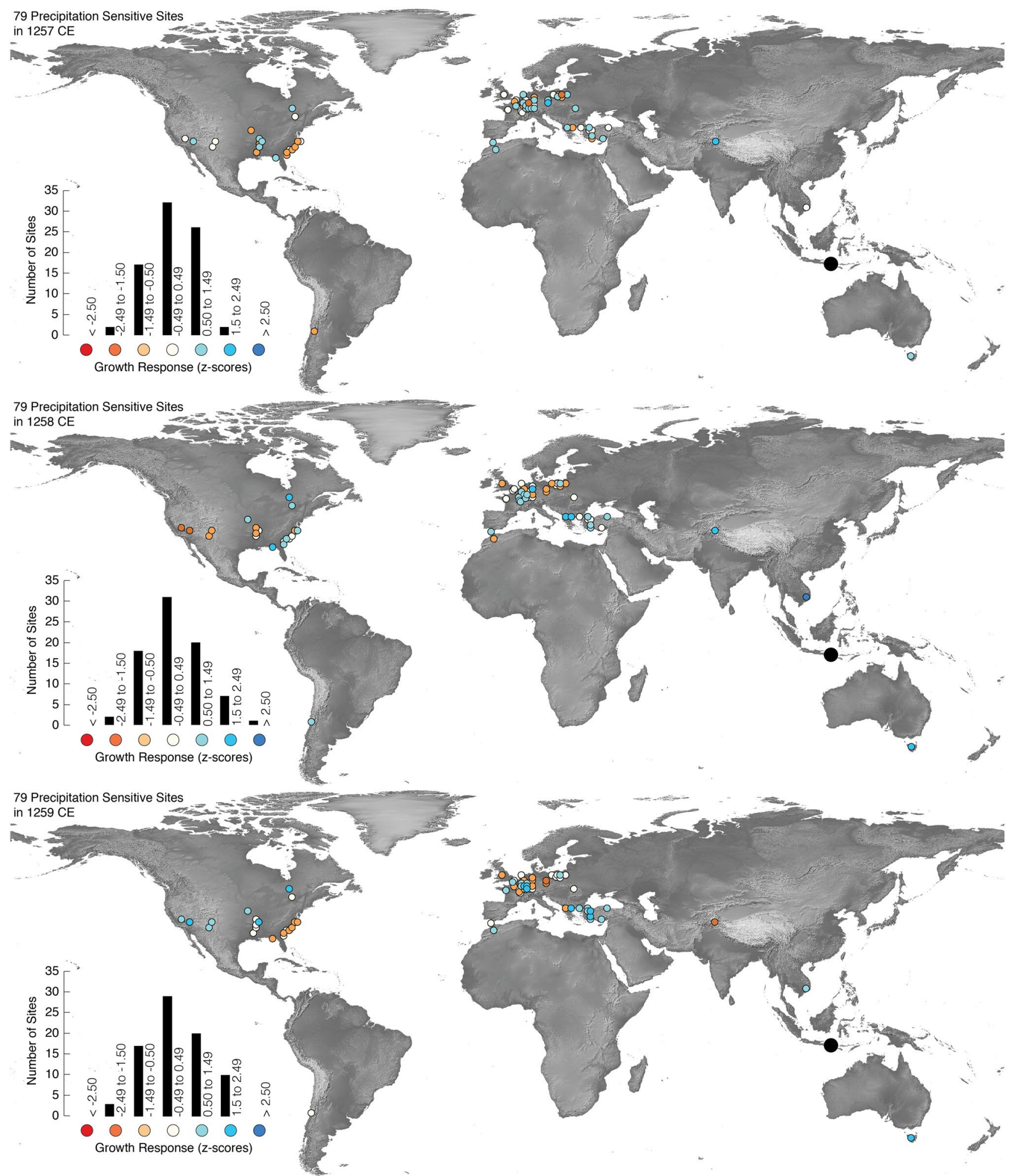

Fig. 5 Growth response of 79 precipitation-sensitive tree-ring width (TRW) chronologies in 1257, 1258 and 1259 (top to bottom). Negative anomalies of the normalized timeseries (with a mean of zero and a standard deviation of one for the period 1200-1300), indicative of drier summer conditions, are shown in light orange, orange and red, whereas positive anomalies refer to wetter summer conditions and range from light to dark blue 

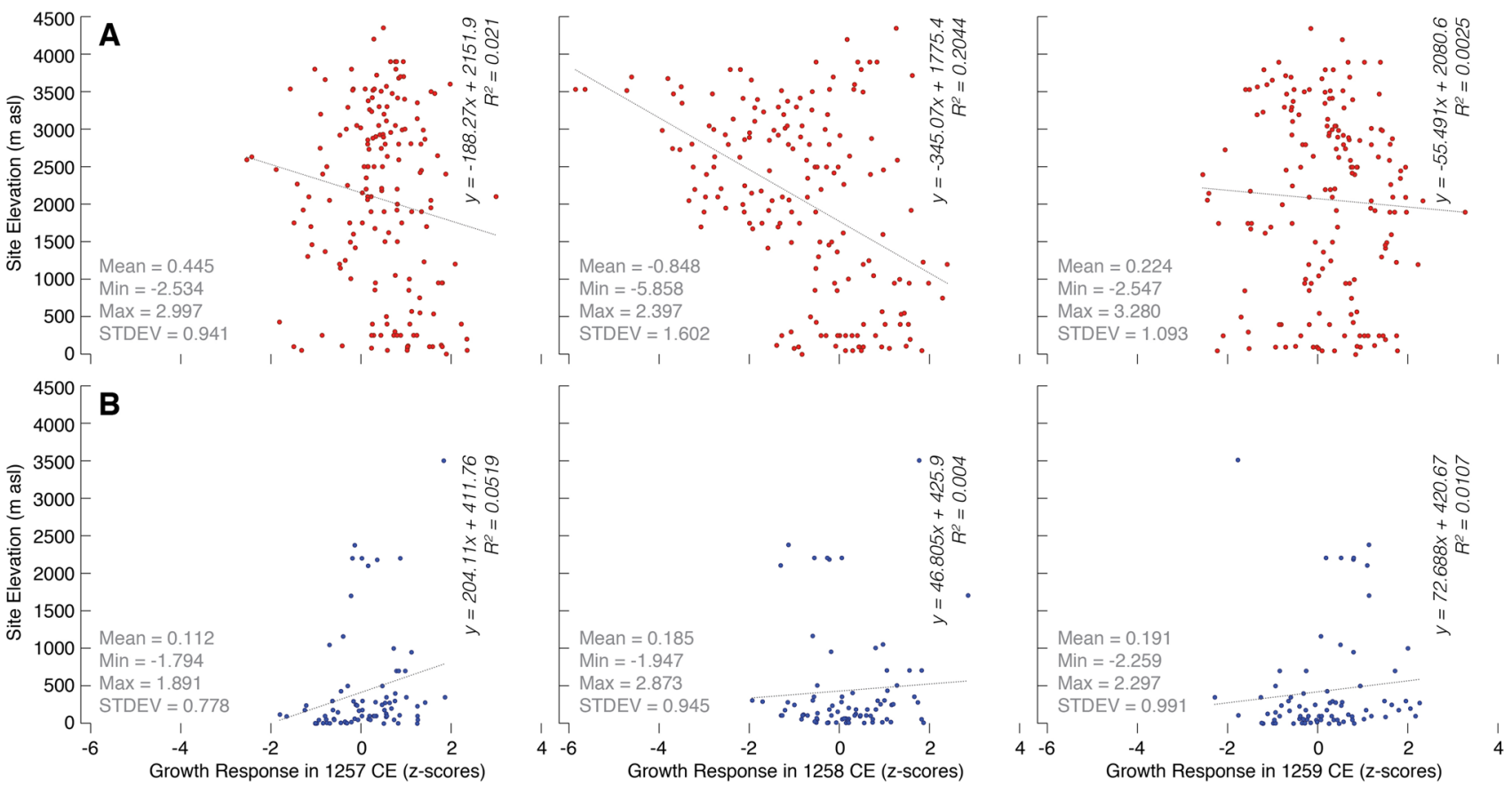

Fig. 6 a Relationship between the growth response and site elevation of 170 temperature-sensitive tree-ring width (TRW) chronologies in 1257, 1258 and 1259 (left to right). b Relationship between the growth response and site elevation of 79 precipitation-sensitive TRW chronologies in 1257, 1258 and 1259 (left to right). Z-scores were calculated relative to the period $1200-1300$
High-elevation sites in the western US and Canada show a strong growth decline in 1257 that may reflect the impact of radiative forcing caused by Samalas aerosol (Fig. 4). If this deflection is an indication of post-volcanic boreal summer cooling, it would suggest an eruption at least weeks before the end of the growing season of these trees, i.e., before around August 1257, which would be consistent with the eruption window suggested by Oppenheimer (2003a) and Lavigne et al. (2013). Our network, however, reveals the strongest cooling in 1258 across much of the $\mathrm{NH}$ midlatitudes, consistent with previously published regional evidence (Büntgen et al. 2017; Guillet et al. 2017; Piermattei et al. 2020). The strongest growth depression across the northern boreal forest of Scandinavia and Siberia in 1259 is consistent with previous reports of delayed northern Eurasia summer cooling 2 years after volcanic eruptions (Esper et al. 2015), as well as with documentary evidence from the Altai (Guillet et al. 2017).

The few TRW chronologies from South America and Australasia mainly indicate warmer conditions between 1257 and 1259 , which challenges the argument of a globally consistent cooling response to the Samalas eruption (Neukom et al. 2019). Warmer SH summers in 1258 and 1259 might be related to El Niño conditions and a positive phase of the Pacific North America pattern, as evidenced by increased growth rates in Alaska (Rohli and Vega 2018). The observed response pattern at North American sites contributes to the debate around connections between volcanism and ENSO (Mann et al. 2005; Stevenson et al. 2018; Dee et al. 2020; Robock 2020), and more generally on the possible linkages between climate oscillations and volcanic eruptions (Mann et al. 2021). In addition, interactions between changes in external climate forcing and direct climate effects on temperature and precipitation over the $\mathrm{SH}$ are considerably influenced by the internal state of background variability that is affected by the large oceanic coverage of the SH. The amount of sea-ice around Antarctica potentially also impacts the state of the Antarctic Oscillation and associated synoptic-scale climate variability in the aftermath of volcanic eruptions. This somewhat deviating and counterintuitive response of SH climate to volcanic eruptions is further reflected in the spatial extent and temporal structure of anomalous cold periods during the last millennium (PAGES 2k Consortium 2013), such as the Little Ice Age.

A more complex picture is drawn by the 79 predominantly precipitation-sensitive TRW chronologies, which show a high level of spatiotemporal heterogeneity between 1257 and 1259. The chronologies from the eastern US indicate summer drying in 1257, whereas the central US sites show a mixed response in this year. Positive precipitation anomalies across the US east coast in 1258 coincide with summer drying in the southwest, which is generally in line with the post-eruptive response patterns simulated by the HadCM3 and CMIP5 climate models (Iles et al. 2013; Iles 

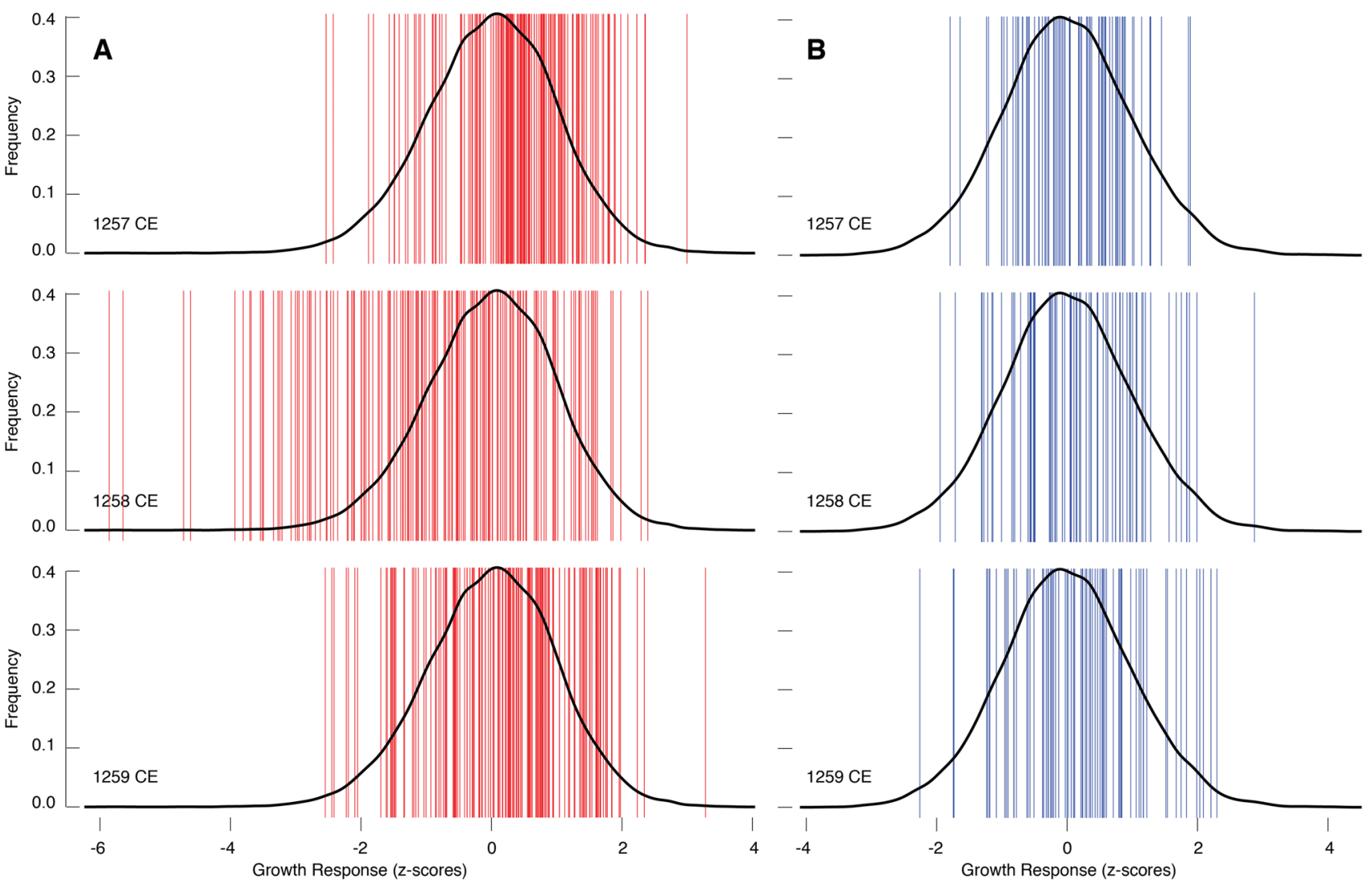

Fig. 7 a Distribution of the growth response of 170 temperaturesensitive tree-ring width (TRW) chronologies in 1257, 1258 and 1259 (top to bottom), relative to the full thirteenth century distribution (black line). b Distribution of the growth response of 79 precip-

and Hegerl 2014) and independent proxy evidence (Tejedor et al. 2021a). The inverse response pattern in 1259 suggests North American internal climate variability played an important role in modulating precipitation regimes in the aftermath of the Samalas eruption (Tejedor et al. 2021a; Stevenson et al. 2018). The European chronologies indicate dryer northern and wetter southern European summers in 1259, which is in line with previous findings (Rao et al. 2017; Di Cosmo et al. 2021). This dipole pattern possibly reflects a negative phase of the East Atlantic Pattern (EAP), or a negative phase of the summer NAO (Liu et al. 2020). However, other studies did not find any dramatic central European hydroclimatic response to the Samalas eruption (Raible et al. 2016; Büntgen et al. 2021; Tejedor et al. 2021a). Though there is some evidence for wetter summers following large tropical eruptions in southeast Asia (Anchukaitis et al. 2010; Buckley et al. 2010), the overall limited data availability from Asia hinders any further resolution of the relationship, if any. Moreover, the enhanced NH summer cooling after the Samalas eruption may have shifted the ITCZ southward, resulting in wetter conditions in South America and Australasia (Tejedor et al. 2021a; Liu et al. itation-sensitive TRW chronologies in 1257, 1258 and 1259 (top to bottom), relative to their general distribution in the thirteenth century (black line)

2016), though we reiterate that the paucity of TRW sites in the SH precludes definitive conclusions. Nevertheless, the precipitation-sensitive TRW chronologies in South America and Australia indicate wetter conditions in 1258, which is in line with previous findings (Tejedor et al. 2021a).

Depending on the volcanic forcing used (Table 1), most PMIP3 models have their lowest NH surface temperatures for the thirteenth century in 1258 (Crowley and Unterman 2013), whereas CCSM4, IPSL-CM5A-LR and BCCCSM1.1 indicate their coldest summers in 1259 . The only model that uses the Gao et al. (2008) forcing and produces its lowest value in 1258 is GISS-E2-Rp122. Based on an earlier volcanic forcing dataset (Crowley et al. 2008), FGOALS-gl simulates the lowest summer temperature in 1257. In addition to uncertainty in the timing of the eruption, which hinders the comparison with independent proxy data (Büntgen and Oppenheimer 2020), different background conditions and forcing datasets also affect the simulated climate response to the Samalas eruption (Lohmann et al. 2013; Schmidt et al. 2011). The overall weak proxymodel association may be best explained by a combination of parameterisation uncertainty in the climate models 


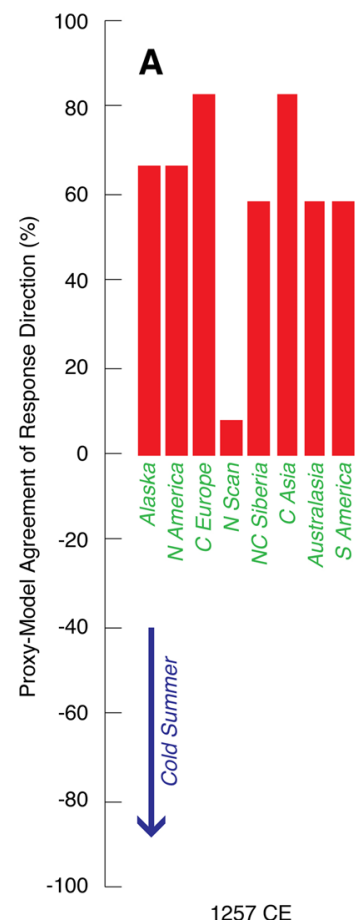

$1257 \mathrm{CE}$

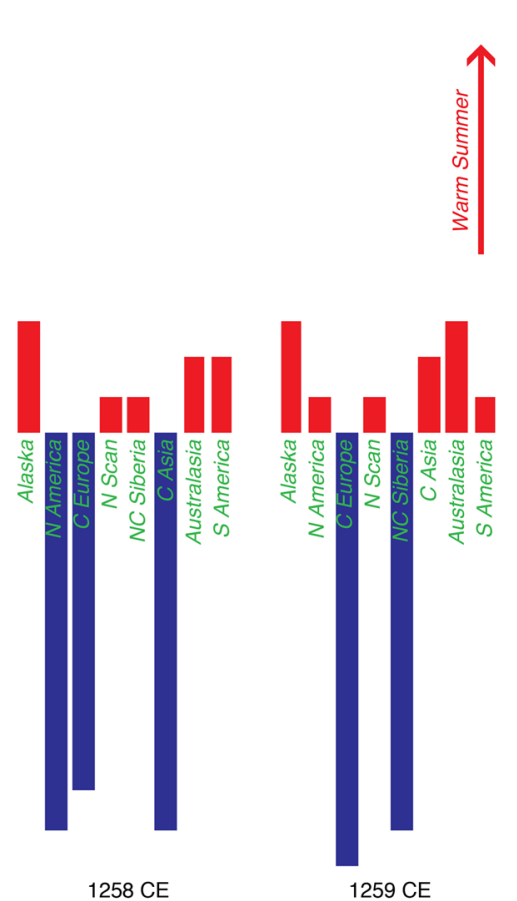

$1258 \mathrm{CE}$

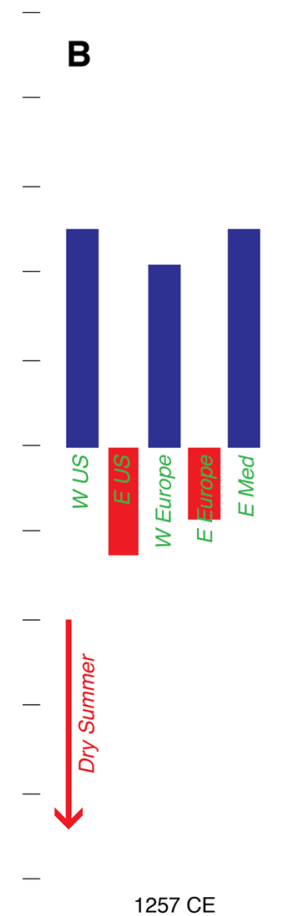

$1257 \mathrm{CE}$


$1258 \mathrm{CE}$

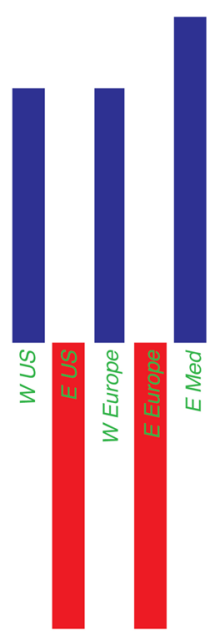

$1259 \mathrm{CE}$
Fig. 8 a Directional agreement between temperature-sensitive treering width (TRW) chronologies in eight spatial clusters and corresponding output from 12 model simulations of regional summer temperature anomalies in 1257, 1258 and 1259 (see Table 1 for model details). The eight temperature clusters represent parts of Alaska (Alaska), North America (N America), central Europe (C Europe), northern Scandinavia (N Scan), north-central Siberia (NC Siberia), central Asia (C Asia), Australasia (Australasia) and South America (S America), and contain 7, 90, 16, 14, 5, 20, 4 and 11 TRW chronolo-

(Gettleman and Rood 2016; Diaz and Vera 2018), aerosol lifetime differences and microphysical processes that are variably represented in the models (Timmreck et al. 2009; Timmreck 2012), and mixed signals in the TRW chronologies (Fritts 1976).

\section{Conclusions}

We have presented a near global network of 249 annuallyresolved and absolutely-dated regional TRW chronologies that reflect high-frequency summer temperature or precipitation variability, span the period of the Samalas eruption, and capture its effects on surface climate. Our analysis contributes in several ways to understanding the timing and climatic impacts of the eruption: (1) We provide tree-ring evidence for a possible eruption date of Samalas between May and July of 1257 , followed by a distinct cold spell across the mid-latitudes of the $\mathrm{NH}$ in 1258, delayed cooling at the highnorthern latitudes in 1259, and some indication for generally warmer growing seasons in the SH between 1257 and 1259 . (2) We do not identify any dramatic hydroclimate tree-ring gies, respectively. b Directional agreement between precipitationsensitive tree-ring width (TRW) chronologies in five spatial clusters and their corresponding output from 12 model simulations of regional summer precipitation anomalies in 1257, 1258 and 1259. The five precipitation clusters represent parts of the western U (W US), the eastern US (E US), western Europe (W Europe), eastern Europe (E Europe) and the eastern Mediterranean (E Med), and contain 4, 17, 25, 10 and 14 TRW chronologies, respectively

responses to the Samalas eruption. (3) We find no tree-ring evidence for globally coherent and exceptionally colder or wetter summers in the aftermath of the Samalas eruption.

Due to spatial data biases and mixed climate signals, future research would profit from focussing on the development of multi-centennial to millennial-long tree-ring chronologies in those regions of both hemispheres that are still underrepresented. Such endeavours should include wood anatomical, density and isotopic measurements, which contain less biological memory and may represent different seasonal windows compared to the classical TRW data.

Acknowledgements Two anonymous referees kindly commented on earlier versions of this manuscript. We are particularly thankful to all producers and contributors of tree-ring data, which were obtained via the ITRDB (https://www.ncei.noaa.gov/products/paleoclimatology/ tree-ring), or compiled by Steffen Walz (who was responsible for data collection and preparation during an initial phase of this project). Ulf Büntgen and Jan Esper received support from the SustES projectAdaptation strategies for sustainable ecosystem services and food security under adverse environmental conditions (CZ.02.1.01/0.0/0.0/16_0 19/0000797), and the ERC Advanced project Monostar (AdG 882727). 
Author contributions UB conceived the study. SHS and UB processed data and performed analyses. SW provided climate model simulations and $\mathrm{CO}$ offered insights into the eruption history. PJK, JE, AP, AC, FR, WT and AK organised tree-ring data and contributed to discussion $\mathrm{UB}, \mathrm{CO}, \mathrm{SHS}, \mathrm{JE}$ and PJK wrote the paper with input from all others.

\section{Declarations}

Conflict of interest The authors declare no competing interests.

Open Access This article is licensed under a Creative Commons Attribution 4.0 International License, which permits use, sharing, adaptation, distribution and reproduction in any medium or format, as long as you give appropriate credit to the original author(s) and the source, provide a link to the Creative Commons licence, and indicate if changes were made. The images or other third party material in this article are included in the article's Creative Commons licence, unless indicated otherwise in a credit line to the material. If material is not included in the article's Creative Commons licence and your intended use is not permitted by statutory regulation or exceeds the permitted use, you will need to obtain permission directly from the copyright holder. To view a copy of this licence, visit http://creativecommons.org/licenses/by/4.0/.

\section{References}

Anchukaitis KJ, Buckley BM, Cook ER, Cook BI, D’Arrigo RD, Ammann CM (2010) Influence of volcanic eruptions on the climate of the Asian monsoon region. Geophys Res Lett 37:L22703

Anchukaitis KJ, Breitenmoser P, Briffa KR et al (2012) Tree rings and volcanic cooling. Nat Geosci 5:836-837

Battipaglia G, Frank DC, Büntgen U, Dobrovolny P, Brazdil R, Pfister C, Esper J (2010) Five centuries of Central European temperature extremes reconstructed from tree-ring density and documentary evidence. Glob Planet Change 72:182-191

Braconnot P, Harrison SP, Otto-Bliesner B et al (2011) The paleoclimate modelling intercomparison project contribution to CMIP5. CLIVAR Exch 56:15-19

Braconnot P, Harrison SP, Kageyama M et al (2012) Evaluation of climate models using palaeoclimatic data. Nat Clim Change 2:417-424

Buckley BM, Anchukaitis KJ, Penny D, Fletcher R, Cook ER, Sano M, Nam LC, Wichienkeeo A, Minh TT, Hong TM (2010) Climate as a contributing factor in the demise of Angkor, Cambodia. Proc Natl Acad Sci USA 107:6748-6752

Büntgen U, Oppenheimer C (2020) The importance of 'year zero' in interdisciplinary studies of climate and history. Proc Natl Acad Sci USA 117:32845-v32847

Büntgen U, Frank DC, Nievergelt D, Esper J (2006) Summer temperature variations in the European Alps, AD 755-2004. J Clim 19:5606-5623

Büntgen U, Krusic PJ, Verstege A et al (2017) New tree-ring evidence from the Pyrenees reveals western Mediterranean climate variability since medieval times. J Clim 30:5295-5318

Büntgen U, Wacker L, Galván JD et al (2018) Tree rings reveal globally coherent signature of cosmogenic radiocarbon events in 774 and 993 CE. Nat Commun 9:3605

Büntgen U, Arseneault D, Boucher E et al (2020) Prominent role of volcanism in common era climate variability and human history. Dendrochronologia 64:125757

Büntgen U, Allen K, Anchukaitis KJ et al (2021) The influence of decision-making in tree ring-based climate reconstructions. Nat Commun 12:3411
Camarero JJ, Gazol A, Sánchez-Salguero R et al (2021) Global fading of the temperature - growth coupling at alpine and polar treelines. Glob Change Biol 27:1879-1889

Collier MA, Jeffrey SJ, Rotstayn LD et al (2011) The CSIRO-Mk3.6.0 atmosphere-ocean GCM: participation in CMIP5 and data publication. In: International congress on modelling and simulation, Perth Australia, vol 19, pp 2691-2697

Cook ER, Peters K (1981) The smoothing spline: a new approach to standardizing forest interior tree-ring width series for dendroclimatic studies. Tree-Ring Bull 41:45-53

Cook ER, Peters K (1997) Calculating unbiased tree-ring indices for the study of climatic and environmental change. Holocene 7:361

Cook ER, Briffa KR, Meko DM, Graybill DA, Funkhouser G (1995) The 'segment length curse' in long tree-ring chronology development for palaeoclimatic studies. Holocene 5:229-237

Cook ER, Krusic PJ, Peters K, Holmes RL (2017) Program ARSTAN (2020) autoregressive tree-ring standardization program. TreeRing Laboratory of Lamont-Doherty Earth Observatory, Palisades

Crowley TJ, Unterman MB (2013) Technical details concerning development of a $1200 \mathrm{yr}$ proxy index for global volcanism. Earth Syst Sci Data 5:187-197

Crowley TJ, Zielinski G, Vinther B, Udisti R, Kreutz K, Cole-Dai J, Castellano E (2008) Volcanism and the little ice age. PAGES Newsl 16:22-23

D’Arrigo R, Frank D, Jacoby G, Pederson N (2005) Spatial response to major volcanic events in or about AD 536, 934 and 1258: frost rings and other dendrochronological evidence from Mongolia and northern Siberia: Comment on R. Stothers 'Volcanic dry fogs, climate cooling, and plague pandemics in Europe and the middle east' (Climatic Change, 42, 1999). Int J Clim 25:1437-1454

Dee SG, Cobb KM, Emile-Geay J, Ault TR, Edwards RL, Cheng H, Charles CD (2020) No consistent ENSO response to volcanic forcing over the last millennium. Science 367:1477-1481

Di Cosmo N, Wagner S, Büntgen U (2021) Climate and environmental context of the Mongol invasion of Syria and defeat at 'Ayn Jālūt (1258-60 CE). Erdkunde 75:87-104

Diaz LB, Vera CS (2018) South American precipitation changes simulated by PMIP3/CMIP5 models during the Little Ice Age and the recent global warming period. Int J Clim 38:2638-2650

Dufresne J, Foujols M-A, Denvil S et al (2013) Climate change projections using the IPSL-CM5 Earth System Model: from CMIP3 to CMIP5. Clim Dyn 40:2123-2165

Esper J, Schneider L, Krusic PJ et al (2013) European summer temperature response to annually dated volcanic eruptions over the past nine centuries. Bull Volcanol 75:736-750

Esper J, Schneider L, Smerdon JE, Schöne BR, Büntgen U (2015) Signals and memory in tree-ring width and density data. Dendrochronologia 35:62-70

Esper J, Krusic PJ, Ljungqvist FC et al (2016) Ranking of tree-ring based temperature reconstructions of the past millennium. Quat Sci Rev 145:134-151

Franke J, Frank D, Raible CC, Esper J, Brönnimann S (2013) Spectral biases in tree-ring climate proxies. Nat Clim Change 3:360-364

Fritts H (1976) Tree rings and climate. Academic Press, New York

Galván JD, Camarero JJ, Ginzler C, Büntgen U (2014) Spatial diversity of recent trends in Mediterranean tree growth. Environ Res Lett 9:084001

Gao C, Robock A, Ammann C (2008) Volcanic forcing of climate over the past 1500 years: an improved ice core-based index for climate models. J Geophys Res A 113:D23111

Gent PR, Danabasoglu G, Donner LJ et al (2011) The community climate system model version 4. J Clim 24:4973-4991

Gettleman A, Rood RB (2016) Demystifying climate models. A users guide to earth system models. Springer, Berlin

Giorgetta M, Jungclaus J, Reick C et al. (2012) CMIP5 simulations of the Max Planck Institute for Meteorology (MPI-M) based on the 
MPI-ESM-LR model: he sstClim experiment, served by ESGF. World Data Centre for Climate

Gordon C, Cooper C, Senior CA et al (2000) The simulation of SST, sea ice extents and ocean heat transports in a version of the Hadley Centre coupled model without flux adjustments. Clim Dyn 16:147-168

Guillet S, Corona C, Stoffel M et al (2017) Climate response to the Samalas volcanic eruption in 1257 revealed by proxy records. Nat Geosci 10:123-128

Helama S, Lindholm M, Timonen M, Eronen M (2004) Detection of climate signal in dendrochronological data analysis: a comparison of tree-ring standardization methods. Theor Appl Climatol 79:239-254

Hellmann L, Agafonov L, Ljungqvist FC et al (2016) Diverse growth trends and climate responses across Eurasia's boreal forest. Environ Res Lett 11:074021

Iles CE, Hegerl G (2014) The global precipitation response to volcanic eruptions in the CMIP5 models. Environ Res Lett 9:104012

Iles CE, Hegerl GC, Schurer AP, Zhang X (2013) The effect of volcanic eruptions on global precipitation. J Geophys Res 118:8770-8786

Institute of Atmospheric Physics (2017) WCRP CMIP5: the LASGIAP team FGOALS-gl model output for the past1000 experiment. Centre for Environmental Data Analysis, London

Jones P, Osborn T, Briffa K (1997) Estimating sampling errors in largescale temperature averages. J Clim 10:2548-2568

Jungclaus JH, Bard E, Baroni M et al (2017) The PMIP4 contribution to CMIP6 - part 3: the last millennium, scientific objective and experimental design for the PMIP4 past1000 simulations. Geosci Model Dev 10:4005-4033

Lavigne F, Degeai J-P, Komorowski J-C et al (2013) Source of the great AD 1257 mystery eruption unveiled, Samalas volcano, Rinjani Volcanic Complex, Indonesia. Proc Natl Acad Sci USA 110:16742-16747

Liu F, Chai J, Wang B (2016) Global monsoon precipitation responses to large volcanic eruptions. Sci Rep 6:24331

Liu B, Liu J, Ning L et al (2020) The role of Samalas mega volcanic eruption in European summer hydroclimate change. Atmosphere 11:1182

Ljungqvist FC, Thejll P, Björklund J, Gunnarson BE, Piermattei A, Rydval M, Seftigen K, Støve B, Büntgen U (2020) Assessing non-linearity in European temperature-sensitive tree-ring data. Dendrochronologia 59:125652

Lohmann G, Pfeiffer M, Laepple T et al (2013) A model-data comparison of the Holocene global sea surface temperature evolution. Clim past 9:1807-1839

Mann ME, Cane MA, Zebiak SE, Clement A (2005) Volcanic and solar forcing of the tropical Pacific over the past 1000 years. $\mathrm{J}$ Clim 18:447-456

Mann ME, Fuentes JD, Rutherford S (2012) Underestimation of volcanic cooling in tree-ring based reconstructions of hemispheric temperatures. Nat Geosci 5:202-205

Mann ME, Steinman BA, Brouillette DJ, Miller SK (2021) Multidecadal climate oscillations during the past millennium driven by volcanic forcing. Science 371:1014

Mets KD, Armenteras D, Davalos LM (2017) Spatial autocorrelation reduces model precision and predictive power in deforestation analyses. Ecosphere 8:e01824

Neukom R, Gergis J (2011) Southern Hemisphere high-resolution palaeoclimate records of the last 2000 years. Holocene 22:501-524

Neukom R, Steiger N, Gómez-Navarro JJ, Wang J, Werner JP (2019) No evidence for globally coherent warm and cold periods over the preindustrial Common Era. Nature 571:550-554

Oppenheimer C (2003a) Ice Core and palaeoclimatic evidence for the timing and nature of the great mid-13th century volcanic eruption. Int J Climatol 23:417-426
Oppenheimer C (2003b) Climatic, environmental and human consequences of the largest known historic eruption: Tambora volcano (Indonesia) 1815. Prog Phys Geogr 27:230-259

Osborn TJ, Briffa KR, Jones PD (1997) Adjusting variance for samplesize in tree-ring chronologies and other regional-mean time-series. Dendrochronologia 15:89-99

PAGES 2k Consortium (2013) Continental-scale temperature variability during the past two millennia. Nat Geosci 6:339-346

PAGES Hydro2k Consortium (2017) Comparing proxy and model estimates of hydroclimate variability and change over the Common Era. Clim past 13:1851-1900

PAGES2K-PMIP3 Group (2015) Continental-scale temperature variability in PMIP3 simulations and PAGES $2 \mathrm{~K}$ regional temperature reconstructions over the past millennium. Clim past 11:1673-1699

Palais JM, Germani MS, Zielinski GA (1992) Interhemispheric transport of volcanic ash from a 1259 AD volcanic-eruption to the Greenland and Antarctic ice sheets. Geophys Res Lett 19:801-804

Phipps S et al (2013) Paleoclimate data-model comparison and the role of climate forcings over the past 1500 years. J Clim 26:6915-6936

Piermattei A, Crivellaro A, Krusic PJ et al (2020) A millennium-long 'Blue Ring' chronology from the Spanish Pyrenees reveals severe ephemeral summer cooling after volcanic eruptions. Environ Res Lett 15:124016

Polvani LM, Camargo SJ (2020) Scant evidence for a volcanically forced winter warming over Eurasia following the Krakatau eruption of August 1883. Atmos Chem Phys 20:13687-13700

Predybaylo E, Stenchikov G, Wittenberg AT, Osipov S (2020) El Niño/ Southern Oscillation response to low-latitude volcanic eruptions depends on ocean pre-conditions and eruption timing. Commun Earth Environ 1:12

Raible CC, Brönnimann S, Auchmann R et al (2016) Tambora 1815 as a test case for high impact volcanic eruptions: earth system effects. Interdiscip Rev Clim Change 7:569-589

Rao MP et al (2017) European and Mediterranean hydroclimate responses to tropical volcanic forcing over the last millennium. Geophys Res Lett 44:5104-5112

Reinig F, Wacker L, Jöris O et al (2021) Precise date for the Laacher See eruption synchronizes the Younger Dryas. Nature 595:66-69

Robock A (2020) Comment on "No consistent ENSO response to volcanic forcing over the last millennium". Science 369:eabc0502

Rohli RV, Vega AJ (2018) Climatology. Jones \& Bartlett Learning, Burlington

Russell GL, Miller JR, Rind D (1995) A coupled atmosphere-ocean model for transient climate change studies. Atmos Ocean 33:683-730

Schmidt A, Robock A (2015) Volcanism, the atmosphere and climate through time. In: Schmidt A, Fristad K, Elkins-Tanton L (eds) Volcanism and global environmental change. Cambridge University Press, Cambridge, pp 195-207

Schmidt GA, Ruedy R, Hansen JE et al (2006) Present day atmospheric simulations using GISS Model E: comparison to in-situ, satellite and reanalysis data'. J Clim 19:153-192

Schmidt GA, Jungclaus JH, Ammann CM (2011) Climate forcing reconstructions for use in PMIP simulations of the last millennium (v1.0). Geosci Model Dev 4:33-45

Schneider DP, Ammann CM, Otto-Bliesner BL, Kaufman DS (2009) Climate response to large, high-latitude and low-latitude volcanic eruptions in the Community Climate System Model. J Geophys Res A 114:D15101

Schneider L, Smerdon JE, Büntgen U et al (2015) Revising midlatitude summer temperatures back to A.D. 600 based on a wood density network. Geophys Res Lett 42:4556-4562

Schulman E (1956) Dendroclimatic changes in semiarid america. University of Arizona Press, p Tucson 
Sigl M, Winstrup M, McConnell J et al (2015) Timing and climate forcing of volcanic eruptions for the past 2,500 years. Nature 523:543-549

Stenchikov G (2021) The role of volcanic activity in climate and global changes. In: Letcher TM (ed) Climate change, 3rd edn. Elsevier

Stevenson S, Powell BS, Cobb KM, Nusbaumer J, Merrifield MA, Noone D (2018) Twenties century seawater $\delta^{18} \mathrm{O}$ dynamics and implications for coral-based climate reconstruction. Paleoceanogr Paleoclimatol 33:606-625

Stoffel M, Khodri M, Corona C et al (2015) Estimates of volcanicinduced cooling in the Northern Hemisphere over the past 1,500 years. Nat Geosci 8:784-788

Stothers RB (2000) Climatic and demographic consequences of the massive volcanic eruption of 1258. Clim Change 45:361-374

Tejedor E, Steiger NJ, Smerdon JE, Serrano-Notivoli R, Vuille M (2021a) Global hydroclimatic response to tropical volcanic eruptions over the last millennium. Proc Natl Acad Sci USA 118:e2019145118

Tejedor E, Steiger N, Smerdon JE, Serrano-Notivoli R, Vuille M (2021b) Global temperature responses to large tropical volcanic eruptions in paleo data assimilation products and climate model simulations over the last millennium. Paleoceanogr Paleoclim 36:e2020PA004128

Timmreck C (2012) Modeling the climatic effects of large explosive volcanic eruptions. Wires Clim Change 3:545-564

Timmreck C, Lorenz SJ, Crowley TJ, Kinne S, Raddatz TJ, Thomas MA, Jungclaus JH (2009) Limited temperature response to the very large AD 1258 volcanic eruption. Geophys Res Let 36:L21708

Toohey M, Sigl M (2017) Volcanic stratospheric sulfur injections and aerosol optical depth from 500 BCE to 1900 CE. Earth Syst Sci Data 9:809-831
Vidal CM, Komorowski JC, Métrich N et al (2015) Dynamics of the major plinian eruption of Samalas in 1257 AD (Lombok, Indonesia). Bull Volcanol 77:73

Vidal C, Métrich N, Komorowski JC et al (2016) The 1257 Samalas eruption (Lombok, Indonesia): the single greatest stratospheric gas release of the Common Era. Sci Rep 6:34868

Vitali V, Büntgen U, Bauhus J (2017) Silver fir and Douglas fir are more tolerant to extreme droughts than Norway spruce in southwestern Germany. Glob Change Biol 23:5108-5511

Wade DC, Vidal CM, Abraham L (2020) Reconciling the climate and ozone response to the $1257 \mathrm{CE}$ Mount Samalas eruption. Proc Natl Acad Sci USA 117:26651-26659

Wilson R, Anchukaitis K, Briffa KB et al (2016) Last millennium northern hemisphere summer temperatures from tree rings: part I: the long-term context. Quat Sci Rev 134:1-18

Wu T, Li W, Ji J et al (2013) Global carbon budgets simulated by the Beijing Climate Center Climate System Model for the last century. J Geophys Res 118:4326-4347

Zambri B, LeGrande AN, Robock A, Slawinska J (2017) Northern Hemisphere winter warming and summer monsoon reduction after volcanic eruptions over the last millennium. J Geophys Res A 122:7971-7989

Zhu F, Emile-Geay J, Hakim GJ, King J, Anchukaitis KJ (2020) Resolving the differences in the simulated and reconstructed temperature response to volcanism. Geophys Res Lett 47:e2019GL086908

Publisher's Note Springer Nature remains neutral with regard to jurisdictional claims in published maps and institutional affiliations. 